\title{
Револьверные волоконные световоды с полой сердцевиной и лазеры на их основе
}

\author{
И.А. Буфетов ${ }^{*}$, А.Ф. Косолапов, А.Д. Прямиков, А.В. Гладышев \\ Научный центр волоконной оптики РАН \\ *E-mail: iabuf@fo.gpi.ru
}

DOI:10.31868/RFL2018.43-44

Револьверные волоконные световоды (RF) - это новый тип волоконных световодов с полой сердцевиной (HCF), которые впервые были предложены и реализованы в 2011 году в НЦВО РАН [1]. Поперечные сечения некоторых полых RF из кварцевого стекла, реализованных до настоящего времени, представлены на Рис. 1(c,d).

RF изготавливаются методом сборки заготовки из капилляров с последующей вытяжкой световодов. (см. Рис. 1). Оптические потери в них имеют зонную структуру (Рис. 2а) и, как показано экспериментально, могут быть снижены до $\approx 50$ дБ/км в ближнем ИК диапазоне и до $\approx 1$ дБ/м в среднем ИК (на длине волны 4.4 мкм).

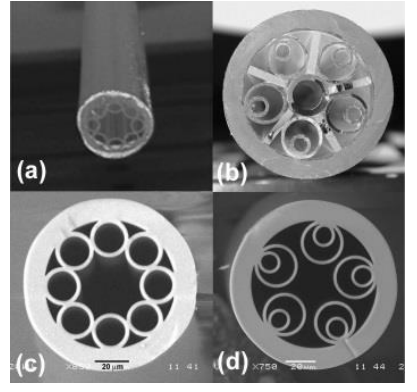

Рис. 1. Поперечные сечения оптических элементов на основных этапах изготовления RF. (а) заготовка RF с одиночными капиллярами, прилегающими друг к другу [1]; (b) собранная заготовка RF c кварцевыми элементами между двойными капиллярами, Ø25 мм; (c) изображение сечения вытянутого RF c касающимися капиллярами; (d) изображение сечения вытянутого RF c двойными вложенными некасающимися капиллярами, Ø110 мкм [2].
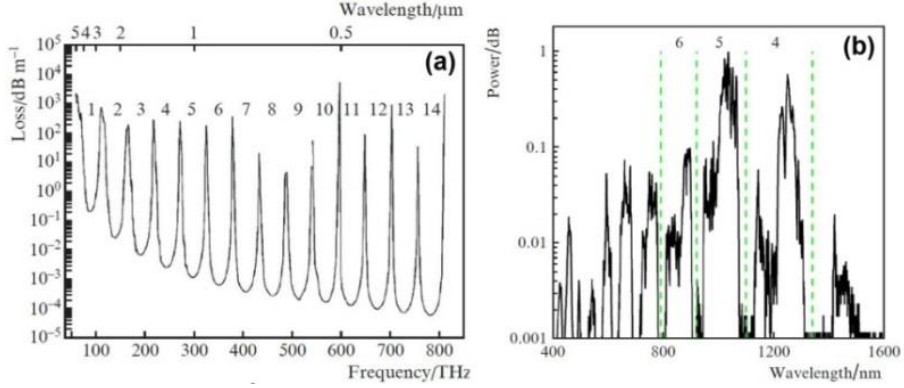

Рис. 2. (а) - теоретические потери для фундаментальной моды, рассчитанные для спектрального интервала, соответствующего 14 зонам пропускания RF; (b) измеренный спектр лазерного излучения на выходе из световода длиной 3 м при энергии импульса на входе 110 мкДж [3].

Введение молекулярных газов в сердцевину полых световодов превращает их в активную среду для волоконных лазеров. Например, лазерная генерация в спектральном диапазоне 3.1 - 3.2 мкм была получена в СПС, заполненных ацетиленом [4]. При этом генерация осуществлялась за счет создания инверсии населенностей на колебательно-вращательных уровнях ацетилена с помощью оптической накачки. Другим методом генерации длинноволнового лазерного излучения в СПС является ВКР в газах, заполняющих сердцевину этих 
световодов. Особенно привлекательным в данной схеме выглядит использование молекулярного водорода, точнее - наиболее распространенного легкого изотопа водорода 1Н. В однопроходной схеме ВКР-лазера (Рис. За) была достигнута выходная мощность на длине волны 4.4 мкм более 1 Вт (Рис. 3b) [5]. Накачка при этом осуществлялась наносекундными импульсами (Рис. 3a).
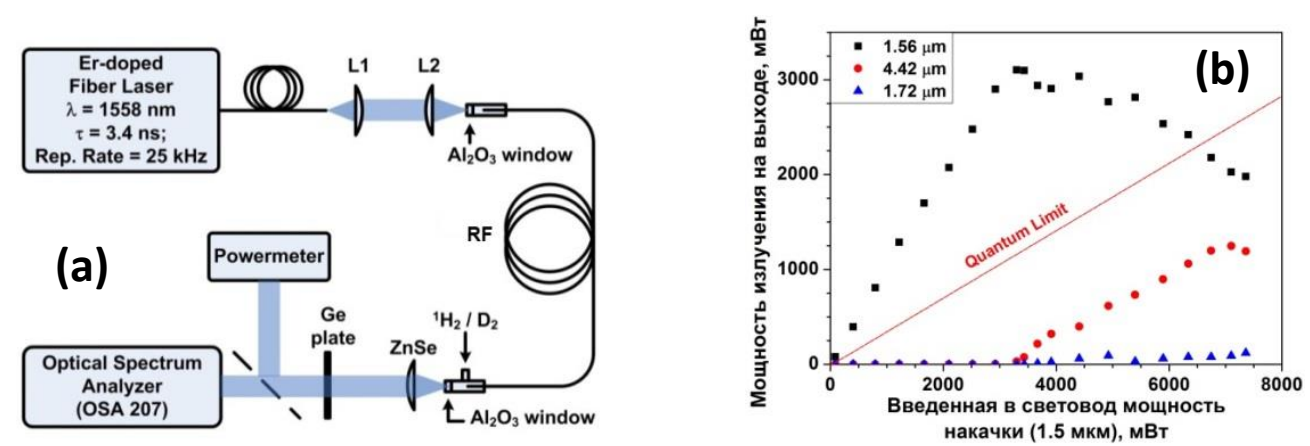

Рис. 3. (а) Оптическая схема ВКР-лазера на $\mathrm{RF}\left({ }^{1} \mathrm{H}_{2}\right)$. L1 и L2 - линзы из плавленого кварца, $\mathrm{Al}_{2} \mathrm{O}_{3}$ сапфировые окна газовых ячеек, $\mathrm{ZnSe}$ - коллимирующая линза на выходе волоконного лазера, $\mathrm{Ge}$ - германиевая пластинка толщиной 2 мм. (b) - Зависимость средней мощности излучения на выходе волоконного ВКР-лазера от средней мощности накачки, введенной в световод.

Использование ультракоротких импульсов накачки позволяет получать за счет нелинейных эффектов излучение с широким спектром, несмотря на зонную структуру спектра пропускания RF. Так, была экспериментально продемонстрирована возможность получения многозонного суперконтинуума в RF c одиночными разделенными капиллярами в оболочке [3]. При вводе в световод, заполненный атмосферным воздухом, лазерных импульсов длительностью 205 фс с энергией 110 мкДж на длине волны 1028 нм получен суперконтинуум со спектральным диапазоном, перекрывающим область длин волн 415-1593 нм с 11-ю зонами пропускания RF.

Исследование выполнено за счет гранта Российского научного фонда №16-19-10513

\section{Литература}

1 A.D. Pryamikov, A.S. Biriukov et al. Opt. Express 19, 1441-1448 (2011).

2 A. F. Kosolapov, G. K. Alagashev et al. Quantum Electronics, 46, 267-270 (2016).

3 Yu.Yatsenko, E.N. Pletneva et al. Quantum Electronics, 47, 553-560 (2017).

4 M. R. A. Hassan, F. Yu, W. J. Wadsworth, J. C. Knight, Optica, 3, 218-221 (2016).

5 M.S. Astapovich, A.V. Gladyshev et al. To be published (2018). 